\title{
Müşteri Memnuniyetinin Üç Faktör Teorisine Göre Kongre Oteli Ürün Özelliklerinin Sınıflandırılması
}

\author{
A Classification of Conference Hotel Products Attributes by Three Factor Theory of Customer Satisfaction
}

\author{
Özgür DAVRAS* \\ *Dr. Öğr. Üyesi, Süleyman Demirel Üniversitesi IïBF Turizm İşletmeciliği Doğu Kampüsü, 32260, Isparta. \\ E-posta: ozgurdavras@sdu.edu.tr \\ ORCID No: 0000000190374193
}

MAKALE BILGILERI

Makale işlem bilgileri:

Gönderilme tarihi: 14 Kasım 2018

Düzeltme: 4 Ocak 2019

Düzeltme: 21 Ocak 2019

Kabul: 31 Ocak 2019

Anahtar sözcükler: Kongre ürün özellikleri, Doğrusal olmayan ilişki, Müşteri memnuniyeti, Ceza ödül karşıtlığı analizi.

\section{ARTICLE INFO}

Article history:

Submitted: 14 November 2018

Resubmitted: 4 January 2019

Resubmitted: 21 January 2019

Accepted: 31 January 2019

Key words: Conference product attributes, Nonlinear relationship, Customer satisfaction, Penalty-reward contrast analysis.

\section{ÖZ}

Müşteri memnuniyeti işletmelerin finansal performanslarının belirleyicisi olması sebebiyle, kongre oteli ürün özelliklerinin müşteri memnuniyeti üzerindeki etkilerinin bilinmesi önem arz etmektedir. Alanyazında, ürün özelliklerinin performansı ile müșteri memnuniyeti arasında doğrusal bir ilișkinin olduğu kabul edilmesine rağmen, son yıllarda gerçekleştirilen bazı çalışmalar bu ilişkinin doğrusal yönlü olmayabileceğini ortaya koymuştur. Bu çalışmada, kongre oteli ürün özelliklerinin müşteri memnuniyeti üzerindeki doğrusal olmayan etkileri incelenerek müşteri memnuniyetinin üç faktör teorisine göre ürün özelliklerinin sınıflandırılması amaçlanmıștır. Bu amaç doğrultusunda, Antalya Belek bölgesinde faaliyet göstermekte olan beș yıldızlı otel ișletmesine toplantı ve kongre amacıla gelen 427 kongre katılımcısı üzerinde bir anket çalışması uygulanmıştır. Elde edilen verilere gerçekleştirilen Ceza-Ödül karşıtlığı analizi sonuçlarına göre konaklama hizmetleri, oda temizliği ve otelin konumu heyecan faktörleri; çamașırhane hizmetleri, yiyecek-içecek hizmetleri, ikramlar ve kongre organizasyonu temel faktörler olarak sınıflandırılmıştır. Bu sonuca göre, temel faktörler içinde yer alan özelliklerin performansının artırııması müşteri memnuniyetsizliğini önlemeye katkı sağlarken, heyecan faktörleri içinde yer alan özelliklerin performansının arttırılması müşteri memnuniyetini olumlu yönde etkileyecektir.

\section{GiRiş}

Özellikle ekonomik katkısı, lobi gücü ve uluslararası arenada tanıtım yönleri ile ön plana çıkan kongre turizmi, katılımcıların tatil yapmak için değil, farklı türdeki toplantılara katılmak amacıyla seyahat ettiği alternatif turizm türüdür. Uluslararası Kongre ve Konvansiyon Birliği (ICCA-2013) raporunda, 1963-2012 y1lları arası yapılan 173.432 toplantının, 1.795'i (yüzde1) 1963-
1967 yılları arasında, 8.585'i (yüzde 4,9) 19831987 yılları arasında, 54.844'ü (yüzde 31,6) 20082012 yılları arasında gerçekleştiği belirtilmektedir. Aynı rapora göre kongre organizasyonlarına katılanların sayısı 1963-1697 periyodunda yaklaşık iki milyon iken, 2008-2012 döneminde yaklaşık olarak 22 milyona yükseldiği tahmin edilmektedir. Uluslararası Kongre ve Konvansiyon Birliği (ICCA-2017) raporunda ise yalnızca 2017 
yılında 12.558 kongre düzenlendiği, yaklaşı olarak dört milyon kişinin bu kongre organizasyonlarına katıldığı ve katılımcıların kongre başına gerçekleştirdikleri ortalama harcamanın 2200 dolar olduğu belirtilmektedir. Son yıllarda büyük bir gelişim gösteren ve iş turizminin alt türü olan kongre turizminde, kongre organizatörleri toplantı mekânları olarak çoğunlukla konaklama işletmelerini tercih etmektedirler (Aksu, Yılmaz ve Gümüş 2013: 171). İş amaçlı gelen kongre katılımciları (delegeler), hem destinasyon hem de konaklama işletmeleri için büyük bir potansiyel oluşturmaktadır. Özellikle konaklama işletmelerinin sunduğu kongre ürün özelliklerinin performans1, delegelerin memnuniyet düzeylerini etkilemesinin yanı sıra, onların gelecek dönemlerde tatil amaçlı olarak tekrar ziyaret etme niyetlerinin belirleyicisi olacaktır (Siu, Wan ve Dong 2012). Dolayisiyla toplantı ve kongre turizmine yönelik faaliyet göstermekte olan otel işletmelerinin, delegelerin bakış açısıyla sunduğu hizmet kalitelerini ölçmeleri ve hangi hizmet özelliğinin memnuniyet üzerinde daha etkili olduğunu bilmeleri önem arz etmektedir.

Alanyazında, ürün özellikleri ile müşteri memnuniyeti arasında doğrusal bir ilişkinin olduğu varsayımı benimsense de son yıllarda yapılan bazı çalışmalar (Örneğin Kuo, Chen ve Lin 2010; Albayrak 2015; Kocabulut ve Albayrak 2017), bu ilişkinin doğrusal yönlü olmayabileceğini ortaya koymuştur. Buna göre bir ürün özelliğinin olumsuz performansı, müşteri memnuniyeti üzerinde olumlu performanstan daha büyük bir etkiye sahip olabilmektedir (Deng, Kuo ve Chen 2008). Müşteri memnuniyetinin üç faktör teorisi olarak da bilinen bu varsayıma göre; ürün özellikleri temel, performans ve heyecan faktörleri olarak s1nıflandırılmakta ve sınıflandırılan faktörlerin her biri müşteri memnuniyeti üzerinde farklı bir etkiye sahip olmaktadır (Allegre ve Grau 2011).

Ürün özellikleri ile müşteri memnuniyeti arasındaki doğrusal olmayan ilişki, turizm alanyazınında destinasyon özellikleri (Albayrak ve Caber 2013), otel animasyon programları (Mikulić ve Prebežac 2011), yiyecek-içecek hizmetleri (Chen 2012), web sitesi özellikleri (Zhang ve Cole 2016; Kocabulut ve Albayrak 2017) gibi farklı alanlar- da araştırılmasına rağmen, kongre oteli ürün özellikleri ile müşteri memnuniyeti arasındaki doğrusal olmayan ilişkileri ele alan çalışmaya rastlanmamıştır. Alanyazındaki bu boşluğun doldurulması düşüncesiyle bu çalışma, kongre oteli ürün özellikleri ile müşteri memnuniyeti arasındaki doğrusal ve doğrusal olmayan ilişkiyi inceleyerek, ürün özelliklerini müşteri memnuniyetinin üç faktör teorisine göre sinıflandırmayı amaçlamaktadır. Ayrıca sınıflandırılan kongre ürün özelliklerini katılımcıların milliyetlerine (Türk ve Rus) göre karşılaştırarak, aralarındaki farklılıkları belirlemek çalışmanın alt amacını oluşturmaktadır. Bu sayede, otel işletmelerinin daha yüksek müşteri memnuniyeti sağlamaları için kısıtlı kaynaklarını doğru ürünlere aktarabilmeleri ve farklı pazardaki müşteri davranışlarının yöneterek pazarlama stratejileri geliştirmeleri mümkün olabilecektir.

\section{KONGRE OTELI ÜRÜN ÖZELLIKLERI}

Kongre turizmi, bireylerin kesin bir program çerçevesinde kendi meslekleri, belirli bir bilimsel alan veya konuda bilgi alışverişi yapmak amacıyla ikamet ettikleri yerler dışında yaptıkları seyahat ve konaklamalarda ortaya çıan olaylar ve ilişkiler bütünüdür (Aksu vd. 2013: 3). Turizm sezonunu uzatması, istihdam olanaklarını ve turizm gelirlerini artırması, bölgedeki tesislerin tanıtım ve etkin kullanımının yanı sıra gerek ekonomik, kültürel ve sosyal alanlardaki olumlu etkileri (Yozcu ve İçöz 2010) gerekse kitle turizmine göre daha fazla gelir getirmesi (Pechlaner, Zeni ve Raich 2007) sebebiyle kongre turizmi günümüzde oldukça önem kazanmıştır.

Alanyazında, kongre turizmi ile ilgili yapılan çalışmalarda, genellikle kongre turizminin sosyal ve ekonomik etkileri (Pechlaner vd. 2007; Yozcu ve İçöz 2010), delegelerin motivasyonunu etkileyen faktörler (Severt, Wang, Chen ve Breiter 2007; Tretyakevich ve Maggi 2012), destinasyon özellikleri ile imaj1 (Oppermann 1996; Caber, Albayrak ve İsmayıllı 2017) ve kongre şehri/mekanı seçimi (Mair ve Thomson 2009; Elston ve Drapper 2012) gibi konulara odaklanılmıştır. Bunun yanında delegelerin davranışsal tutumlarını ele alan araştırmalar da mevcuttur. Kongre turiz- 
minin müşterisi olan delegeler, kitle turizmi için büyük bir potansiyel oluşturmaktadır. Delegeler hem kongre organizatörlerine hem konaklama işletmelerine hem de bölgenin ekonomik olarak kalkınmasına fayda sağlarlar. Ayrıca genel olarak kongre organizasyonundan memnun kalmaları, ağızdan ağza iletişim ile bölgenin ve konakladıkları otel işletmesinin tanıtımına katkı sağlayabilecekleri gibi gelecek zamanda tatil amaçlı tekrar ziyaret etme eğiliminde bulunabilirler. Nitekim Siu vd.'nin (2012) yaptıkları nicel bir araştırmada, yüksek performans seviyesindeki kongre hizmet özelliklerinin memnuniyeti arttırdığ ve bunun da delegelerin tekrar ziyaret etme niyetini olumlu yönde etkilediği tespit edilmiştir. Bir başka çalışmada Zhang, Qu ve Ma (2010) Çin'de düzenlenen iki büyük kongre organizasyonunda sunulan konaklama hizmetleri, yiyecek-içecek hizmetleri ve fiziksel olanakların (toplantı salonları, alışveriş merkezleri gibi) müşteri memnuniyetini arttırdığını ortaya koymuşlardır. Tanford, Montgomery ve Nelson (2012) Las Vegas'ta kongre organizasyonuna katılımı ve memnuniyeti etkileyen beş faktör (kongre programı, ağ iletişimi, sosyal akviteler, kongre yeri -konum- ve maliyet olmak üzere) tespit etmişler ve bunlardan kongre program boyutunun katılımciların farklı bir kongreye katılımında belirleyici bir rol üstlendiği sonucunu ortaya koymuşlardır. Severt vd. (2007) Güney Amerika'da bir kongre organizasyonuna katılan delegeler üzerinde yapmış oldukları çalışmalarında, delegelerin kongreye katılım motivasyonlarını etkileyen beş faktör (etkinlikler, iletişim ağ olanakları, kongrenin uygun olması, eğitim faaliyetleri ve ürün olmak üzere) ortaya koymuşlar ve eğitim faaliyetleri, genel memnuniyet, ağızdan ağza iletişim ve tekrar ziyaret etme niyeti arasında istatistiki açından anlamlı ilişkiler tespit etmişlerdir.

Whitfield ve Webber (2011) İngiltere'de yaptığ çalışmalarında, daha büyük iletişim ağ olanakları, sergi organizasyonlarının artması ve teknik hizmet olanaklarının iyileştirilmesinin katılımcıların tekrar ziyaret etme niyetini arttıracağını göstermişlerdir. Hilliard ve Baloğlu (2008) otel güvenliği ve güvenlik özelliklerinin, kongre organizatörlerinin kongre otel seçim kriterleri üzerindeki etkilerini inceledikleri çalışmalarında, 20 güvenlik özelliğinden somut güvenlik özellikleri ve personel eğitimi (sertifikalı personel) özelliklerinin kongre oteli seçiminde etkili olduğunu belirlemişlerdir. Yiyecek hizmet alanlarının delegelerin memnuniyeti ve tekrar ziyaret etme niyeti üzerindeki etkilerini inceleyen Kim, Lee ve Love (2009), yiyecek kalitesinin memnuniyet üzerinde belirleyici bir özellik olduğunu ve katılımcıların tekrar ziyaret niyetini olumlu yönde etkilediğini tespit etmiş̧lerdir. Kuo vd. (2010) kongre oteli hizmet özelliklerinin delege memnuniyeti üzerindeki etkilerini incelediklerini çalışmalarında, personel eğitiminin memnuniyetin en önemli belirleyicisi olduğunu ortaya koymuşlardır. McCabe ve Weeks (1999) Sydney'de dört ve beş yıldızlı otel işletmelerindeki kongre hizmeti sunan departmanların rolünü ve işlevini inceledikleri çalışmalarında; ilgili departmanların, kongre organizasyonlarında kalifiye personel çalıştırdı ğını ve kongre rezervasyonlarının daha kısa sürede yapılmasına özen gösterdiğini ortaya koymuşlardır.

\section{MÜŞTERI MEMNUNIYETININ ÜÇ FAKTÖR TEORISi}

Alanyazında genellikle ürün özellikleri ile müşteri memnuniyeti arasında doğrusal bir ilişki varsayımı benimsendiğinden, yapılan çalışmalarda regresyon analizi, önem-performans veya yap1sal eşitlik modelleme gibi geleneksel yöntemler kullanılmaktadır. Son yıllarda yapılan bazı çalışmalarda bu ilişkinin doğrusal yönlü olmadığının tespit edilmesi, ürün özelliklerinin müşteri memnuniyeti açısından taşıdığı önemin, özelliklerin performans seviyelerine göre değiştiğini ortaya koymuştur. Bundan dolayı geleneksel yöntemler tercih edildiğinde işletmelerin kısıtlı kaynaklarını yanlış alanlara aktarılması riski söz konusu olmaktadir (Albayrak 2015). Bu riski ortadan kaldırmak ve performansı arttırılması gereken birincil ürün özelliklerini tespit etmek amacıyla Kano, Seraku, Takahashi ve Tsjui (1984) müşteri memnuniyetinin üç faktör teorisini önermiştir. Kano vd.'nin (1984) Herzberg, Mausner ve Snyderman'ın (1959) çift faktörlü iş doyumu teorisinden esinlenerek ortaya koydukları müşteri memnuniyetinin üç faktör teorisi, ürün özelliklerini müşteri memnuniyeti üzerindeki değişen 
etkilerine göre; temel, performans, heyecan, ters ve fark yaratmayan faktörler olarak beş grupta sinıflandırmaktadır. Kano modeli olarak bilinen bu teori, araştırmacıların ters ve farklılık yaratmayan faktörleri dikkate almaması sebebiyle son zamanlarda "Üç Faktör Teorisi" olarak ifade edilmiştir (Kocabulut ve Albayrak 2017). Müșteri memnuniyetini daha etkili yönetmek için kullanılan bu teori, müşteri memnuniyeti için geliştirilmesi gereken birincil ürün özelliklerini tanımlamaya yardımcı olan bir yöntemdir (Füller ve Matzler 2008). Başka bir ifadeyle hangi ürün özelliklerinin müşteri memnuniyetini arttırdığının belirlenmesinde ve sıralanmasında, işletme kaynaklarının etkin kullanımı için beklentilerin sınıflandırılması ve bu sınıflandırmaya göre dağılım yapılmasında ve işletmenin pazarlama stratejilerinin belirlenmesinde önemli rol oynamaktadır (Zhang ve Cole 2016). Bu teori, bir ürün özelliğinin etkisinin, ürünün performansına göre değiştiğini varsaymaktadır. Üç Faktör Teorisi, doğrusal olmayan ilişkiye dayanarak, ürün özelliklerini temel, performans ve heyecan faktörleri olarak sınıflandırmaktadır (Şekil 1).

Temel faktörler, ürün özelliklerinin düşük performans göstermesi durumunda memnuniyetsizlik yaratan, yüksek performans göstermesi durumunda memnuniyete yol açmayan asgari gereksinimlerini ifade etmekte olup, müşteriler için sağlanması gereken minimum hizmetleri kapsamaktadır (Matzler ve Sauerwein 2002). Performans faktörler, müşteri memnuniyetiyle doğrusal bir ilişkiye sahip olup (Matzler ve Sa-

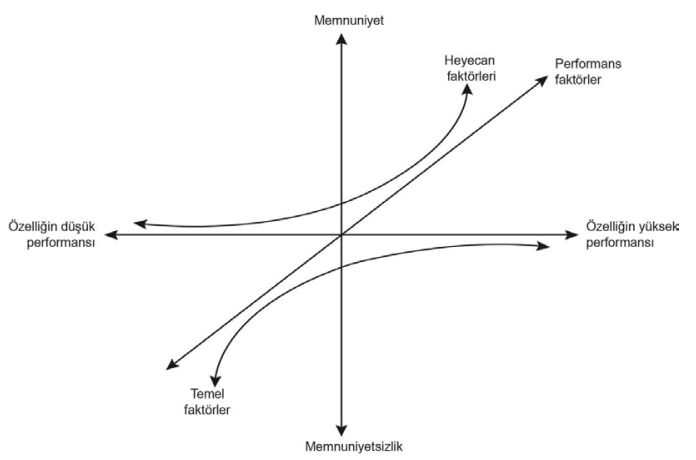

Şekil 1. Müşteri Memnuniyetinin Üç Faktör Teorisi uerwein 2002) özellik yüksek performans gösterdiğinde memnuniyet yaratan, düşük performans gösterdiğinde memnuniyetsizlik yaratan faktörlerdir (Albayrak 2015). Heyecan faktörleri ise temel faktörlerin aksine, ürün özelliğinin yüksek performans göstermesi durumunda müşteri memnuniyetini olumlu yönde etkilemektedirler. Özellik, düşük performans gösterse bile herhangi bir müşteri memnuniyetsizliği oluşmayacaktır. Yüksek memnuniyet yaratma potansiyeli olan bu faktörler müşteriler için beklenmeyen ve sürpriz değerlerdir ve memnuniyet üzerinde daha büyük bir etkiye sahiptirler (Zhang ve Cole 2016). Sonuç olarak temel ve heyecan faktörlerin önemi özelliğin göstereceği performansa bağl1 olmaktadır. Performans düşük olduğunda temel faktörler önemli iken performans yüksek olduğunda önemli değildir. Diğer taraftan yüksek performans göstermesi durumunda heyecan faktörleri önem kazanırken, düşük performans göstermesi durumunda önemi azalmaktadır (Deng vd. 2008).

Üç faktör teorisine dayanarak, ürün özellikleri ile müşteri memnuniyeti arasındaki doğrusal olmayan ilişkiler, alanyazında sağlık (Matzler ve Sauerwein 2002), bankacılık (Johnston 1995), insan kaynakları (Matzler ve Renzl 2007) ve otomotiv sektörü (Mittal, Ross ve Baldasare 1998) gibi alanlarda incelenmiştir. Turizm alanında ise uçak bilet satış hizmetleri (Mikulic ve Prebezac 2012), animasyon program özellikleri (Mikulic ve Prebezac 2011), kongre turizm özellikleri (Lee ve Min 2013), yiyecek içecek hizmetleri (Chen 2012), web sitesi içerikleri (Zhang ve Cole 2016) ve destinasyon özellikleri (Albayrak ve Caber 2013) ile müşteri memnuniyeti arasındaki doğrusal olmayan ilişkiler ele alınmıştır. Konaklama işletmelerinde sunulan hizmet özellikleri ile genel memnuniyet arasındaki doğrusal olmayan ilişkileri ele alan araştırmalar da mevcuttur. Örneğin Tontini, Bento, Milbratz, Volles ve Ferrari (2017) otel hizmet özelliklerinin müşteri memnuniyeti üzerindeki doğrusal olmayan etkilerini inceledikleri çalışmalarında, personel tutumu ve oda konforunu temel faktörler içinde sınıfland1rırken diğer hizmet boyutlarını müşteri memnuniyetini açıklamada istatistiki açıdan anlamsız bulmuşlardır. Bir başka çalışmada Matzler, 
Renzl ve Rothenberger (2006) personel tutumu, resepsiyon hizmetleri ve oda özelliklerini temel faktörler, restoran hizmetlerini ise heyecan faktörleri olarak sınıflandırmışlardır. Albayrak ve Caber'in (2015) çalışmasında personel, yiyecekiçecek kalitesi, oda dekorasyonu, genel temizlik, animasyon ve çocuklara yönelik aktiviteler temel faktörler, plaj özelliği ise heyecan faktörü olarak sınıflandırılmıştır.

Ürün özelliklerinin müşteri memnuniyetinin üç faktör teorisine göre sınıflandırılmasında, Ceza-Ödül Karşıtlığı Analizi, Kano Tekniği, Kritik Olay Tekniği, Önem Matrisi gibi teknikler kullanılmaktadır. Bunlardan Ceza-Ödül Karşıtlığ Analizi, müşteri memnuniyeti ölçümünden elde edilen verilerle gerçekleştirilebilmesi ve üç faktörlü yapının tanımlanmasında daha uygulanabilir olması sebebiyle diğer yöntemlere göre daha fazla tercih edilmektedir (Albayrak 2015). Ceza-Ödül Karşıtlığı yöntemi, kukla değişkenli regresyon analizi yardımıyla gerçekleştirilmektedir (Mikulic ve Prebezac 2012). Curvilinear (eğrisel) regresyondan farklı olarak iki değişken arasındaki doğrusal olmayan ilişkinin incelenmesi amacıyla kullanılan kukla değişkenli regresyon analizinde; ürün özelliğine ait değerler (ortalama veya faktör skorları) düşük ve yüksek performans seviyelerinde yeniden kodlanarak, her bir özellik için iki kukla değişken elde edilmektedir. Yeniden kodlanarak elde edilen bütün kukla değişkenler bağımsız değişken ve müşteri memnuniyeti bağımlı değişken olacak şekilde regresyon analizi gerçekleştirilmektedir. Analiz sonucunda her özellik için ilgili özellik performansının müşteri memnuniyeti üzerinde doğrusal olmayan etkisini gösteren iki regresyon katsayısı (biri özelliğin düşük performans seviyesindeki, diğeri yüksek performans seviyesindeki etkiyi gösteren) elde edilmektedir. Elde edilen regresyon katsayıları kıyaslanarak ürün özellikleri, Tablo 1'deki kurala göre sınıflandırılmaktadır. Düşük performans seviyesinde elde edilen katsayı, yüksek performans seviyesinde elde edilen katsayıdan yüksek olan özellikler "temel faktörler"; düşük olanlar "heyecan faktörler"; eşit olanlar (yaklaşık olarak) ise "performans faktörler" olarak sınıflandırılmaktadır (Albayrak 2015).
Tablo 1. Ürün/Hizmet Özelliklerinin Sınıflandırılması ile İlgili Kural

\begin{tabular}{ll}
\hline Temel faktör & $\beta 1<\beta 2$ \\
\hline Performans faktör & $\beta 1 \sim \beta 2$ \\
\hline Heyecan faktörü & $\beta 1>\beta 2$ \\
\hline
\end{tabular}

\section{ARAŞTIRMANIN YÖNTEMI}

Çalışmanın verileri, Antalya-Belek bölgesinde faaliyet göstermekte olan beş yıldızlı bir otel işletmesinde toplantı yapmak amacıyla konaklayan delegelerin, işletmenin sunduğu hizmetlere yönelik değerlendirilmelerinden elde edilmiştir. (Tablo 2). Verilerin elde edilmesinde kullanılacak olan anket formunun hazırlanmasında, Delice (2012) ve Albayrak'ın (2015) çalışmalarında kullandıkları ölçeklerden yararlanılmıştır. Ölçeklerde yer alan maddelerin örnek alınan kongre otelinin sunduğu hizmet özelliklerine uyumluluğu irdelenmiş, araştırma yapılan otelin yöneticisi ve uzman öğretim üyesinin görüş ve önerileri doğrultusunda toplam 13 maddeden oluşan ölçek hazırlanmıştır. Maddeler beşli Likert tipi ölçek ile ölçümlendirilmiştir. Bu şekilde oluşturulan ölçeğin geçerliliğini test etmek amacıyla pilot uygulama yapılmıştır. Pilot uygulama örnek seçilen otel işletmesinde kongre amacıyla gelen 64 katılımcı üzerinde gerçekleştirilmiştir. Elde edilen verilere SPSS 22 paket programı ile güvenilirlik analizi uygulanmış ve analiz sonucunda ölçeğin bir bütün olarak güvenilirliği $\alpha=0,821$ bulunmuştur. Nihai çalışmada kullanılacak bu ölçeğe, katılımcıların demografik özelliklerini belirlemeye yönelik dört soru daha ilave edilerek anketin son hali oluşturulmuştur. Türkçe oluşturulan anket formu bir çeviri şirketi tarafından Rusçaya çevrilmiştir.

Çalışmanın evrenini, Antalya - Belek bölgesinde faaliyet göstermekte olan beş yıldızlı bir otel işletmesinde, Ekim - Kasım 2018 döneminde gerçekleştirilen kongre organizasyonuna katılan delegeler (Türk ve Rus) oluşturmaktadır. Bu dönemin tercih edilmesinin sebebi, otel işletmesinin toplant ve kongre organizasyonlarına bu zaman dilimi içerisinde yoğunlaşmasıdır. Otel işletmesinden alınan bilgilere göre Ekim - Kasım 2018 döneminde gerçekleştirilen toplantı ve kongre 
organizasyonlarına toplam 1789 delege katılmıştır. Bu organizasyonlardan üçü ulusal düzeyde olduğundan (ilaç firması, kozmetik sektörü, otomotiv sektörü) katılımcıların tümü Türklerden oluşmaktadır. Diğer iki toplantı grubu (peş peşe gruplar) Rus bir sigorta şirketinin çalışanlarına eğitim amacıyla yapıldığından katılımcıların tamamı Rus delegelerdir. Anket formu, her toplantı ve kongre organizasyonu sirasinda tüm delegelerin odasına kişi sayısı bazında bırakılmış olup, 509 anketin geri dönüşü olmuştur. Anketlerden 82 adedi, yeterli veri ve anlamlılığa sahip olmadı$\breve{g}$ g ve katılımcıların bilinçsizce doldurduğu tespit edildiği için değerlendirmeye alınmamıştır. Geri kalan 427 anket ise değerlendirmeye alınmıştır.

\section{BULGULAR}

İlk olarak, elde edilen verilerin güvenilirliğini test etmek amacıyla güvenilirlik katsayısı hesaplanmış (Cronbach Alpha) ve 0,887 olarak tespit edilmiştir. Araştırmaya katılanların yüzde52'7'si Türk ve yüzde 47,3'ü Rus'tur. yüzde64,4'ü erkek olup, yüzde62,2'si 31-50 yaş arası, yüzde23,8'i 50 yaş üstü ve yüzde11'i 30 yaş altındadır. Katılımcıların yüzde37,4'ü beş gün, yüzde31,6'sı üç gün, yüzde24,6'sı dört gün ve yüzde6,3'ü iki gün otel işletmesinde konaklamışlardır.
Kongre ürün özelliklerinin performansını ölçmeye yönelik oluşturulan ifadelere ait tanımlayıcı istatistikler Tablo 2'de gösterilmiştir. Tablo 2 incelendiğinde en yüksek ortalama değeri 4,53 ile "Oda Temizliği", "Genel Alanlar" ve "Personel" ifadelerinde; en düşük ortalama değeri 4,04 ile "Sağlık Hizmetleri" ifadesinde olduğu görülmektedir.

Kongre oteli ürün özellikleri ile müşteri memnuniyeti arasındaki doğrusal ilişkiyi incelemek amacıyla regresyon analizi gerçekleştirilmiştir. Regresyon modeli istatistiki açıdan anlamlı olup $(\mathrm{F}=64,630 ; \mathrm{p}=0,000)$ müşteri memnuniyetinin yüzde65'ini açıklamaktadır. Tablo 3 incelendiğinde, müşteri memnuniyetine en yüksek etkiyi yapan hizmet özellikleri kongre organizasyonu $(\beta=0,267)$ ile yiyecek-içecek hizmetleri $(\beta=0,235)$ olduğu görülmektedir. Genel alanlar, sağlık hizmetleri, SPA hizmetleri ve toplantı salonlarına ait özelliklerin müşteri memnuniyeti üzerine etkisi istatistiki açıdan anlamsız olduğundan, bu hizmet özellikleri Albayrak ve Caber (2013) tarafından önerildiği gibi sonraki analizlere dâhil edilmemiştir.

Kongre oteli ürün özellikleri ile genel müşteri memnuniyeti arasındaki doğrusal olmayan ilişkileri incelemek ve kongre otel ürün özellik-

Tablo 2. Kongre Ürün Özelliklerine Ait Tanımlayıcı İstatistikler

\begin{tabular}{lcccr}
\hline Ifade & $N$ & Ort. $^{*}$ & S.S. & Varyans \\
\hline S1-Konaklama Hizmetleri & 411 & 4,37 &, 880 &, 776 \\
\hline S2-Oda Temizliği & 415 & 4,53 &, 806 &, 650 \\
\hline S3-Genel Alanlar & 412 & 4,53 &, 739 &, 546 \\
\hline S4-Çamaşırhane Hizmetleri & 244 & 4,31 &, 862 &, 744 \\
\hline S5-Yiyecek İçecek Hizmetleri & 413 & 4,09 & 1,122 & 1,260 \\
\hline S6-Teknik Servis Hizmetleri & 406 & 4,31 & 1,027 & 1,056 \\
\hline S7-Sağlık Hizmetleri & 160 & 4,04 &, 913 &, 835 \\
\hline S8-Spa Hizmetleri & 256 & 4,18 &, 951 &, 906 \\
\hline S9-Toplantı Salonları & 427 & 4,22 &, 707 &, 500 \\
\hline S10-Kongre Personeli & 416 & 4,53 &, 805 &, 650 \\
\hline S11-Genel Olarak Kongre Organizasyonu & 404 & 4,31 &, 846 &, 716 \\
\hline S12-Otelin Konumu & 409 & 4,35 &, 839 &, 704 \\
\hline S13-Genel Memnuniyet & 427 & 4,35 &, 810 &, 657 \\
\hline \multicolumn{1}{c}{$*$ 1= Çok Yetersiz ........ 5= Çok İyi } & & & Cronbach Alpha: ,887
\end{tabular}


Tablo 3. Kongre Ürün Özellikleri ile Müşteri Memnuniyeti Arasındaki Doğrusal İlişki

\begin{tabular}{lccr}
\hline Özellik & $b$ & $t$ & $p$ \\
\hline Konaklama Hizmetleri &, 097 & 2,941 &, $003^{*}$ \\
\hline Oda Temizliği &, 137 & 3,569 &, $000^{*}$ \\
\hline Genel Alanlar &, 013 &, 309 &, 758 \\
\hline Çamaşırhane Hizmetleri &, 082 & 2,337 &, $020^{* *}$ \\
\hline Yiyecek İçecek Hizmetleri &, 235 & 6,324 &, $000^{*}$ \\
\hline Teknik Servis Hizmetleri &, 063 & 1,947 &, $052^{* * *}$ \\
\hline Sağlık Hizmetleri &,- 023 &,- 672 &, 502 \\
\hline Spa Hizmetleri &, 048 & 1,374 &, 170 \\
\hline Personel &, 113 & 3,049 &, $002^{*}$ \\
\hline Kongre Organizasyonu &, 267 & 5,966 &, $000^{*}$ \\
\hline Otelin Konumu &, 119 & 3,485 &, $001^{*}$ \\
\hline Toplantı Salonları &, 046 & 1,190 &, 235 \\
\hline *p<0,01 **p<0,05 ***p<0,1; $\mathrm{R}^{2}: 0,652 ; \quad \mathrm{F}: 64,630$ \\
$\begin{array}{l}\text { Bağımlı değişken: Müşteri memnuniyeti } \\
\text { mem }\end{array}$
\end{tabular}

lerini sınıflandırmak amacıyla kukla değişkenli regresyon analizi gerçekleştirilmiştir. Bunun için her bir özelliğe ait ortalamalar üç gruba ayrılmış ve en düşük düzeydeki ortalama değerlere sahip olan grup (bir özellikten en düşük düzeyde memnun olan katılımcıların yüzde 33'ü) için $(0,1)$; en yüksek ortalama değerlerine sahip olan grup (bir özellikten en yüksek düzeyde memnun olan müşterilerin yüzde $33^{\prime}$ ü) için $(1,0)$ şeklinde

Tablo 4. Kukla Değişkenli Regresyon Analizi ve Kongre Hizmet Özelliklerinin Sinıflandırılması

\begin{tabular}{lccr}
\hline Hizmet Özellikleri & $\begin{array}{c}\text { Kukla Değişkenli Regresyon } \\
\text { Katsayıları }\end{array}$ & Sınıflama \\
\hline & $\begin{array}{c}\text { Düşük } \\
\text { Performans }\end{array}$ & $\begin{array}{c}\text { Yüksek } \\
\text { Performans }\end{array}$ \\
\hline Konaklama Hizmetleri &,- 052 &, $069 * * *$ & Heyecan \\
\hline Oda Temizliği &,$- 090^{* *}$ &, $070^{* * *}$ & Heyecan \\
\hline Çamaşırhane Hizmetleri &,$- 097^{*}$ &, 055 & Temel \\
\hline Yiyecek Iç̧ecek Hizmetleri &,$- 209 *$ &, 069 & Temel \\
\hline Teknik Servis Hizmetleri &,- 038 &, 055 & - \\
\hline Personel &,$- 083^{* *}$ &,- 034 & Temel \\
\hline Kongre Organizasyonu &,$- 267^{*}$ &, $181 *$ & Temel \\
\hline Otelin konumu &,- 051 &, $089 * *$ & Heyecan \\
\hline *p<0,01 **p<0,05 *** $\mathrm{p}<0,1 ; \quad \mathrm{R}^{2}: 0,614 ;$ & $\mathrm{F}: 33,538$ \\
Bağımlı değişken: Müşteri memnuniyeti & & \\
\hline
\end{tabular}

kodlanmıştır. Bu şekilde, her özellik için düşük ve yüksek performanslı olmak üzere iki, toplamda on altı (iki kukla x sekiz özellik) kukla değişken oluşturulmuştur. Elde edilen on altı kukla değişken bağımsız ve müşteri memnuniyeti bağımlı değişken şeklinde kullanılarak çok değişkenli doğrusal regresyon analizi gerçekleştirilmiştir. Analiz sonucunda her bir özelliğe ait düşük ve yüksek performans seviyelerinde müşteri memnuniyetine etkiyi yansıtan iki ayrı katsayı elde edilmiştir (Tablo 4).

Tablo 4 incelendiğinde, kongre oteli ürün özelliklerinin düşük ve yüksek performans seviyelerinde elde edilen beta katsayılarına göre, kongre ürün özelliklerinin öneminin performans seviyesine göre değişmekte olduğu görülmektedir. Bu durum, katsayıların daha iyi anlaşılabilmesi amacıyla hazırlanan Şekil 2'de açık bir biçimde gösterilmiştir. Düşük performans seviyesinde müşteri memnuniyetine etkisi, yüksek performans seviyesine göre daha yüksek olan "çamaşırhane hizmetleri", "yiyecek-içecek hizmetleri", "personel" ve "kongre organizasyonu" özellikleri temel faktörler olarak sınıflandırılmıştır. Bu özeliklerin performansı, müşteri istek ve gereksinimlerini karşılayabilecek bir seviyede sürdürülmelidir. Yüksek performans seviyesindeki müşteri memnuniyetine etkileri, düşük performans seviyesine göre daha fazla olan "konaklama hizmetleri", "oda temizliği" ve "otelin konumu" özellikleri heyecan faktörleri olarak sinıfland1rılmıştır. Bu üç özelliğin hizmet performansının arttırılması müşteri memnuniyeti seviyesinin yükselmesine olanak sağlayacaktır. "Teknik servis hizmetleri" özelliğinin yüksek ve düşük performans seviyesindeki beta katsayıları istatistiki açıdan anlamsız bulunduğundan, bu özelliğe ait herhangi bir sınıflandırma yapılmamıştır.

Kukla değişkenli regresyon analizi yardımıyla gerçekleştirilen Ceza-Ödül Karşıtlığı analizi ile sinıflandırılan kongre oteli ürün özellikleri, katılımcıların milliyetlerine göre karşılaştırılmıştır (Tablo 5). Personel ve kongre organizasyonu özellikleri, her iki milliyet için temel faktör olarak sınıflandırılmıştır. Bu özeliklerin performansı, her iki örneklem grubunda yer alan katılımcıların istek ve gereksinimlerini karşılayabilecek 


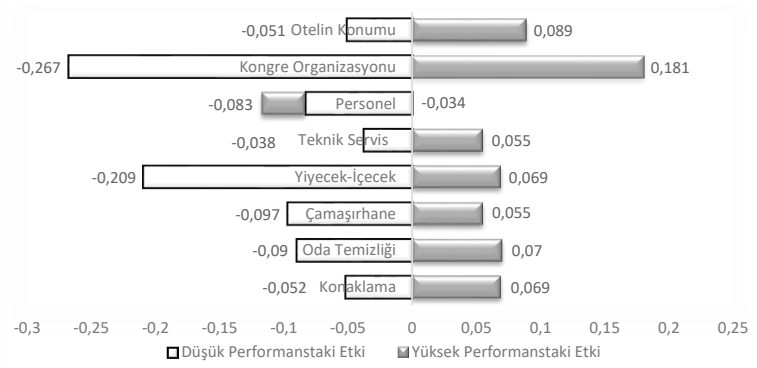

Şekil 2. Ürün Özelliklerinin Müşteri Memnuniyeti Üzerindeki Doğrusal Olmayan Etkileri

bir seviyede devam ettirilmelidir. Oda temizliği ve yiyecek-içecek hizmetleri Rus katılımcılar için temel faktör iken, Türk katılımcılar için heyecan faktörleri içinde yer almaktadır. Dolayısıyla bu iki özelliğin performansının arttırılması, Türk katılımcıların memnuniyet seviyelerinin yükselmesine olanak sağlayacaktır. Konaklama hizmetleri ve otelin konumuna ait düşük ve yüksek seviyedeki beta katsayıları Rus katılımcılar için anlamsız bulunduğundan, bu örneklem grubu için herhangi bir sınıflandırma yapılmamasına rağmen; Türk katılımcıları için istatistiki açıdan anlamlı bulunduğundan, otelin konumu heyecan faktör, konaklama hizmetleri ise temel faktör olarak sınıflandırılmıştır. Dolayısıyla konaklama hizmetleri özelliğine yönelik performansın müşteri beklentilerini karşılayabilecek bir seviyede sürdürülmesi ve otelin konumu özelliğine yönelik performansın arttırılması müşteri memnuni- yet düzeyinin yükselmesine katkı sağlayacaktır. Son olarak teknik servis hizmetine ait düşük ve yüksek seviyedeki beta katsayıları, her iki örneklem grubu içinde anlamsız bulunduğundan bu özelliğe yönelik herhangi bir sınıflandırma (her iki grup için) yapılmamıştır.

\section{SONUÇ VE TARTIŞMA}

Ürün özelliklerinin performansı müşteri memnuniyetini etkilediğinden dolayı, günümüz pazarlama anlayışında hem araştırmacıların hem de yöneticilerin müşterilerin istek ve beklentilerini karşılayabilecek ürün özelliklerinin performanslarını belirlemeleri gerekmektedir. Alanyazında, müşteri memnuniyeti ile ürün özellikleri arasındaki ilişkileri ele alan çalışmalarda, birçok araştırmacı doğrusal ilişki varsayımını benimserken, bazı araştırmacılar doğrusal olmayan ilişki varsayımını benimsemişlerdir. Her iki varsayımın da bilimsel bir değeri olması ve değerli bulgular önermesine rağmen, elde edilen sonuçların bu perspektiflere göre nasıl bir farklılık gösterdiğini araştırmak ve hangisinin diğerinden daha ayrıntılı ve doğru sonuçlar ortaya koyduğuna karar vermek, günümüzde giderek daha da önemli hale gelmiştir. Çalışma sonucunda, kongre otelinde sunulan ürün özellikleri performanslarının müşteri memnuniyeti üzerindeki hem doğrusal hem de doğrusal olmayan etkileri incelenerek ürün özellikleri sınıflandırılmıştır. Daha sonra sınıflandırılan özellikler, katılımcıların milliyetlerine

Tablo 5. Kongre Hizmet Özelliklerinin Milliyete Göre Sınıflandırılması

\begin{tabular}{|c|c|c|c|c|c|c|}
\hline \multirow[t]{2}{*}{ Özellik } & \multicolumn{3}{|c|}{ Türk $\left(R^{2}=0.624\right)$} & \multicolumn{3}{|c|}{$R u s\left(R^{2}=0.609\right)$} \\
\hline & $\begin{array}{r}\text { Düşük } \\
\text { Performans }\end{array}$ & $\begin{array}{r}\text { Yüksek } \\
\text { Performans }\end{array}$ & Sınıflama & $\begin{array}{r}\text { Düşük } \\
\text { Performans }\end{array}$ & $\begin{array}{r}\text { Yüksek } \\
\text { Performans }\end{array}$ & Sinıflama \\
\hline Konaklama Hizmetleri &,$- 098 * * *$ & ,035 & Temel &,- 031 & ,072 & - \\
\hline Oda Temizliği &,- 025 & ,159* & Heyecan &,$- 121 * *$ & ,027 & Temel \\
\hline Çamaşırhane Hizmetleri &,- 043 & ,083 & - &,$- 112 * *$ & ,044 & Temel \\
\hline Yiyecek İçecek Hizmetleri &,$- 109 * * *$ &, $137 * *$ & Heyecan &,$- 266 *$ & ,040 & Temel \\
\hline Teknik Servis Hizmetleri & ,023 & ,024 & - &,- 045 & ,072 & - \\
\hline Personel &,$- 097 * * *$ &,- 063 & Temel &,$- 121 * *$ &,- 003 & Temel \\
\hline Kongre Organizasyonu &,$- 255^{*}$ & 105 & Temel &,$- 251^{*}$ & ,200* & Temel \\
\hline Otelin Konumu & $-140 * *$ & $188^{*}$ & Heyecan &,- 022 & ,032 & - \\
\hline
\end{tabular}


göre karşılaştırılarak aralarındaki farklılıklar tespit edilmiştir. Bu çalışma, farklı tekniklerle elde edilen sonuçların etkisi karşılaştıran az sayıdaki çalışmalardan biri olmasının yanı sıra, konaklama sektöründeki pazar bölümleri arasındaki hizmet algısı değişimlerini anlamada alanyazına katkıda bulunmaktadır.

Kongre oteli ürün hizmetleri ile genel memnuniyet arasındaki doğrusal olmayan ilişkiyi belirlemek amacıyla Ceza-Ödül Karşıtlığı analizi gerçekleştirilmiş ve analiz sonucunda konaklama hizmetleri, oda temizliği ve otelin konumu özellikleri heyecan faktörleri olarak sınıflandırılmıştır. Müşteri memnuniyetinin artırılmasına önemli katkı sağlayan bu üç özelliğe ait müşteri beklentilerinin karşılanması müşteri memnuniyetini artırırken, karşılanmaması durumunda herhangi bir memnuniyetsizliğe neden olmayacaktır. Dolayısıyla otel yöneticilerinin daha yüksek müşteri memnuniyeti sağlayabilmeleri bu özelliklerin performans düzeylerinin arttırılmasına bağlı olduğu söylenebilir. İstatistiki açıdan anlamsız bulunan teknik servis hizmet özelliği haricindeki diğer özellikler (çamaşırhane hizmetleri, yiyecek-içecek hizmetleri, ikramlar ve kongre organizasyonu) temel faktörler olarak sınıflandırılmıştır. Bu özelliklerin genel memnuniyet üzerindeki etkisi sınırlı olduğundan bu özelliklere yönelik müşteri beklentilerinin karşılanması müşteri memnuniyetini artırmamakla beraber, beklentilerin karşılanmaması durumunda müşteri memnuniyetsizliğine neden olacaktır. Yiyecek-içecek hizmetleri ile genel alan temizliğinin temel faktör olarak sinıflandırılması Albayrak (2015) ile Albayrak ve Caber'in (2015) sonuçları ile tutarlılık göstermekle beraber, yiyecek-içecek hizmetlerini heyecan faktörü olarak sinıflandıran Matzler vd.'nin (2006) sonucu ile örtüşmemektedir. Yine personel özelliğinin temel faktör olarak sınıflandırılması alanyazındaki (Matzler vd. 2006; Albayrak ve Caber 2015; Tontini vd. 2017) sonuçlar ile paralellik göstermektedir.

Çalışmanın ikinci aşamasında, doğrusal olmayan ilişki varsayımına göre sınıflandırılan kongre oteli ürün özelliklerinin katılımcıların milliyetlerine (Türk ve Rus) göre farklılık gösterip göstermedikleri test edilmiştir. Her iki örneklem gru- bu üzerinde gerçekleştirilen ceza-ödül karşıtllğ 1 analiz sonucunda, personel ve kongre organizasyonu her iki milliyet için temel faktörler olarak s1nıflandırılmıştır. Dolayısıyla otel yöneticileri her iki pazar bölümü içinde bu iki özelliğe yönelik asgari hizmetleri sunmaları gerekmektedir. Oda temizliği ve yiyecek-içecek hizmet özellikleri Rus katılımcılar için temel faktörler, Türk katılımcılar için heyecan faktörleri olarak sinıflandırıldığından, bu özelliklerin performanslarının artırılması özellikle Türk katılımcıların memnuniyet düzeylerini olumlu yönde etkilemesi kuvvetli olasılıktır. Bu iki özellikle birlikte temel faktörler içinde sınıflandırılan çamaşırhane hizmetleri özelliğine yönelik Rus katılımcıların beklentilerinin karşılanması müşteri memnuniyetinin sürdürülebilmesinde önem arz etmektedir. Türk katılımc1lar için; heyecan faktörleri içinde sınıflandırılan otelin konumunun performansinın artırılmasıyla daha yüksek müşteri memnuniyeti sağlanabilirken, temel faktör olarak sınıflandırılan konaklama hizmetlerinin memnuniyet üzerinde sınırlı etkisinin olduğu söylenebilir. Sonuç olarak her bir pazar bölümü için elde edilen sonuçlar, alg1lanan hizmet kalitesinin milliyete göre değişkenlik gösterdiğini ortaya koymaktadır. Dolayısıyla yüksek müşteri memnuniyeti hedefleyen otel yöneticileri sundukları ürün özelliklerinin her bir pazar dilimi içinde yer alan müşterileri tarafından nasıl algılandığını tespit ederek hangi özelliklerin daha yüksek müşteri memnuniyeti sağladığını bilmeleri işletmelerin başarısı açısından önem arz etmektedir.

Özet olarak çalışmanın sonuçları, ürün özellikleri ile müşteri memnuniyeti arasında doğrusal ve doğrusal olmayan ilişki varsayımına dayanarak, kongre otel ürün özellerini sınıflandırmış ve katılımcıların milliyetlerine göre farklılıklarını ortaya koymuştur. Teorik açıdan bakıldığında, çalışmanın sonuçları konaklama sektöründeki müşteri davranışlarını anlamada bilimsel alana katkıda bulunmaktadır. Otel işletmesinde sunulan hizmetler, performanslarına göre müşteriler tarafından farklı bir şekilde algılanmaktadır. Ürün özelliklerinin genel müşteri memnuniyeti üzerindeki değişen etkileri, yüksek müşteri memnuniyeti sağlamak için müşteri beklentilerini karşılayacak düzeyde hizmet sunulmasının 
önemli olduğunun bir göstergesidir. Aksi takdirde müşteri memnuniyetsizliği ve şikâyetlerinin oluşması kaçınılmaz olacaktır.

Günümüz pazarlama anlayışında; işletmelerin daha yüksek müşteri memnuniyeti sağlayarak finansal performanslarını artırabilmeleri, doğru ürünleri geliştirmelerine bağlı olmaktadır. Bu çalışmada, doğrusal ilişki varsayımı ile gerçekleştirilen çok değişkenli regresyon analizi ve doğrusal olmayan ilişki varsayımı ile gerçekleştirilen Ceza-Ödül Karşıtlığı analizi farklı sonuçlar ortaya koymuştur. İşletmelerin daha yüksek müşteri memnuniyeti sağlamak için kısıtlı kaynaklarını doğru ürünlerde kullanması gerekmekte, dolayısıyla farklı varsayımlarda gerçekleştirilen analiz sonuçlarını dikkate almaları uygun olacaktır. Kongre otellerinin pazar payını artırabilmeleri için potansiyel müşteri konumundaki kongre katılımcılarına yönelik yüksek kalitede hizmet sunmaları ve müşteri memnuniyetinin sürdürebilirliğini sağlamaları gerekmektedir.

Çalışmanın örnekleminin, Antalya Belek bölgesinde yalnızca bir otel işletmesine toplantı ve kongre amaciyla gelen Türk ve Rus müşterilerin seçilmesi bu çalışmanın başlıca sınırını oluşturmaktadır. Çalışmanın farklı bir bölgede, farklı bir zamanda birden fazla otel işletmesinde veya farklı milliyetler üzerinde uygulanmasıyla farklı sonuçlar elde edilebilir. Bu dezavantajlara rağmen çalışma, müşteri memnuniyetinin temel unsurların belirlenmesi ve otel ürünleri ile ilgili müşteri algılarına ilişkin alanyazına önemli katkılar sağlayacaktır. İleride yapılacak çalışmalarda, otel hizmet özellikleri ile müşteri memnuniyeti arasında doğrusal olmayan ilişkinin Önem Matrisi, Kritik Olay Tekniği, Kano Tekniği gibi farklı analiz yöntemleri kullanılarak incelenmesinde yarar bulunmaktadır.

\section{KAYNAKÇA}

Aksu, A.A., Yılmaz, G. ve Gümüş, F. (2013). Örneklerle Kongre ve Fuar Yönetimi. Ankara: Detay Yayıncılık.

Albayrak, T. (2015). Ürün Özelliklerinin Performansı ile Müşteri Memnuniyeti Arasındaki Doğrusal ve Doğrusal Olmayan İlişkinin Karşılaştırılması, Anatolia: Turizm Araştırmaları Dergisi, 26 (1): 17-28.

Albayrak, T. ve Caber, M. (2013). The Symmetric and Asymmetric Influences of Destination Attributes on Overall Visitor Satisfaction, Current Issues in Tourism, 16 (2): 149-166.
Albayrak, T. ve Caber, M. (2015). Prioritisation of the Hotel Attributes According to Their Influence on Satisfaction: A Comparison of Two Techniques, Tourism Management, 46: 43-50.

Alegre, J. ve Garau, J. (2011). The Factor Structure of Tourist Satisfaction at Sun and Sand Destinations, Journal of Travel Research, 50 (1): 78-86.

Caber, M., Albayrak T. ve İsmay1llı T. (2017). Analysis of Congress Destinations' Competitiveness Using Importance Performance Competitor Analysis, Journal of Convention \& Event Tourism, 18 (2): 100-117.

Chen, F.L. (2012). A Novel Approach to Regression Analysis for the Classification of Quality Attributes in the Kano Model: An Empirical Test in the Food and Beverage Industry, Omega, 40 (5): 651-659.

Delice, K. (2012). Kongre Turizmi ve Türkiye'deki Toplant1larda Katılımcı Algısının İncelenmesi: Antalya Yöresinde Bir Uygulama. (Basılmamış Yüksek Lisans Tezi). Antalya: Akdeniz Üniversitesi, Turizm İşletmeciliği ve Otelcilik Ana Bilim Dalı.

Deng, J.W., Kuo F.Y. ve Chen C.W. (2008). Revised Importance-Performance Analysis: Three-Factor Theory and Benchmarking, The Service Industries Journal, 28 (1): 37-51.

Elston, K. ve Draper J. (2012). A Review of Meeting Planner Site Selection Criteria Research, Journal of Convention \& Event Tourism, 13 (3): 203-220.

Füller, J. ve Matzler, K. (2008). Customer Delight and Market Segmentation: An Application of the Three-Factor Theory of Customer Satisfaction on Life Style Groups, Tourism Management, 29 (1): 116-126.

Hilliard, W.T ve Baloğlu S. (2008). Safety and Security as Part the Hotel Servisscape for Meeting Planners, Journal of Convention \& Event Tourism, 9 (1): 15-34.

ICCA (2013). Uluslararası Kongre ve Toplantı Birliği 19632012 Raporu, $h t t p: / / w w w .50 y e a r s . i c c a w o r l d . c o m$, Erişim tarihi: 25 Ekim 2018.

ICCA (2017). Uluslararası Kongre ve Toplantı Birliği İstatistik Raporu, http://www.iccaworld.org, Erişim tarihi: 1 Ocak 2019.

Johnston, R. (1995). The Determinants of Service Quality: Satisfier and Dissatisfier, International Journal of Service Industry Management, 6 (5): 53-71.

Kano, N., Seraku, N., Takahashi, F., Tsuji S., 1984. Attractive Quality and Must Be Quality, Journal of the Japanese Society for Quality Control, 14 (2): 147-156.

Kim, S.Y., Lee, Y.Y. ve Love, C. (2009). A Case Study the Influence of Conference Food Function on Attendee Satisfaction and Return Intention at Corporate Conference, Journal of Convention \& Event Tourism, 10 (3): 211-230.

Kocabulut, Ö. ve Albayrak, T. (2017). Web Sitesi Hizmet Kalitesinin Müșteri Memnuniyetine Etkisi, Anatolia: Turizm Araştırmaları Dergisi, 28 (2): 293-303.

Kuo, M.C, Chen, C.L. ve Lin, Y.S. (2010). Exploring the Relationship Between Hotel-Based Service Attribute Importance and Customer Satisfaction at International Conferences in Taiwan, Journal of Convention \& Event Tourism, 11 (4): 293-313. 
Lee, J.S. ve Min, C. (2013). Prioritizing Convention Quality Attributes from the Perspective of Three Factor Theory: The Case of Academic Association Convention, International Journal of Hospitality Management, 35: 282-293.

Mair, J. ve Thompson, K. (2009). The UK Association Conference Attendance Decision-Making Process, Tourism Management, 30 (3): 400-409.

Matzler, K. ve Sauerwein, E. (2002). The Factor Structure of Customer Satisfaction: An Empirical Test of the Importance Grid and the Penalty-Reward-Constrant Analysis, International Journal of Service Industry Management, 13 (4): 314-332.

Matzler, K., Renzl B. ve Rothenberger, S. (2006). Measuring the Relative Importance of Service Dimensions in the Formation of Price Satisfaction and Service Satisfaction: A Case Study in the Hotel Industry, Scandinavian Journal of Hospitality and Tourism, 6 (3): 179-196.

Matzler, K. ve Renzl, B. (2007). Assessing Asymmetric Effects in the Formation of Employee Satisfaction, Tourism Management, 28: 1093-1103.

McCabe, V. ve Weeks, P. (1999). Convention Services Management in Sydney Four to Five Star Hotels, Journal of Convention \& Exhibition Management, 1 (4): 67-84.

Mikulic, J. ve Prebezac, D. (2011). Evaluating Hotel Animation Programs at Mediterranean Sun and Sea Resorts: An Impact-Asymmetry Analysis, Tourism Management, 32 (3): 688-696.

Mikulic, J. ve Prebezac, D. (2012). Using Dummy Regression to Explore Asymmetric Effects in Tourists Satisfaction: A Cautionary Note, Tourism Management, 33 (3): 713-716.

Mittal, V., Ross, T. ve Baldasare, P.M. (1998). The Asymmetric Impact of Negative and Positive Attribute-Level Performance on Overall Satisfaction and Repurchase Intensions, Journal of Marketing, 62 (1): 33-47.

Oppermann, M. (1996). Convention Destination Image: Analysis of Assocation Meeting Planners' Perception, Tourism Management, 17 (3): 175-182.
Pechlaner, H., Zeni, A. ve Raich F. (2007). Congress Tourism and Leisure Tendencies with Special Focus on Economic Aspects, Tourism Review, 62 (3/4): 32-38.

Severt, D., Wang, Y., Chen, P. ve Breiter, D. (2007). Examining the Motivation, Perceived Performance, and Behavioral Intentions of Convention Attendents: Evidence From Regional Conference, Tourism Management, 28 (2): 399-408.

Siu, M.N., Wan, K.Y.P. ve Dong, P. (2012). The Impact of the Servicescape on the Desire to Stay in Convention and Exhibition Centers: The Case of Macao, International Journal of Hospitality Management, 31 (1): 236-246.

Tanford, S., Montgomery, R. ve Nelson, K. (2012). Factors that Influence Attance, Satisfaction and Loyalty for Conventions, Journal of Convention \& Event Tourism, 13 (4): 290318.

Tontini, G., Bento, G.S., Milbratz, T.C, Volles, B.K. ve Ferrari, D. (2017). Exploring the Nonlinear Impact of Critical Incidents on Customer' General Evaluation of Hospitality Services, International Journal of Hospitality Management, 66: 106-116.

Tretyakevich, N. ve Maggi, R. (2012). Not Just for Business: Some Evidence on Leisure Motivations of Conference Attendents, Current Issues in Tourism, 15 (4): 391-395.

Yozcu, K.Ö. ve İçöz, O. (2010). A Model Proposal on the Use of Creative Tourism Experiences in Congress Tourism and Congress Marketing Mix, Journal of Tourism and Cultural Heritage, 8(3): 105-113.

Whitfield, J. ve Webber, J.D. (2011). Which Exhibition Attributes Create Repeat Visition, International Journal of Hospitality Management, 30 (2): 439-447.

Zhang, Y. ve Cole, S.T. (2016). Dimensions of Lodging Guest Satisfaction among Guest with Mobility Challenges: A-Mixed Method Analysis of Web-Based Texts, Tourism Management, 53: 13-27.

Zhang, L., Qu, H. ve Ma, J. (2010). Examinig the Relationship of Exhibition Attendees' Satisfaction and Expenditure: The Case of Two Major Exhibitions in China, Journal of Convention \& Event Tourism, 11 (2): 100-118.

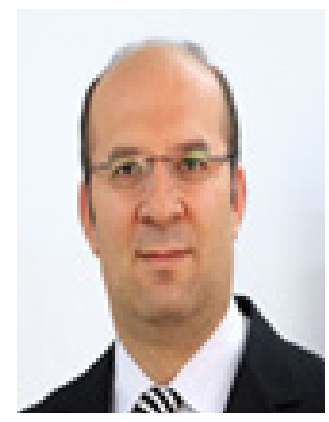

\section{Özgür DAVRAS}

Akdeniz Üniversitesi Turizm İşletmeciliği ve Otelcilik Yüksekokulu'ndan mezun oldu (1999). Yüksek lisans derecesini Akdeniz Üniversitesi Turizm Işletmeciliği ve Otelcilik Ana Bilim Dalı́ndan (2013), doktora derecesini de yine Akdeniz Üniversitesi Turizm İşletmeciliği ve Otelcilik Ana Bilim Dalı́ndan aldı (2017). 2009 yılı itibarıyla Süleyman Demirel Üniversitesi'nde çalışmaya başladı. Öncesinde turizm sektöründe faaliyet gösteren çeşitli otel işletmelerinde ön büro departmanında yönetici olarak çalıştı. Halen Süleyman Demirel Üniversitesi, Iktisadi ve İdari Bilimler Fakültesi Turizm İşletmeciliği Bölümü’nde görev yapmaktadır. Temel çalışma alanları, turizm işletmeciliği, hizmet pazarlaması ve turist davranışlarıdır. 